\title{
Results of surgical treatment of massive localized lymphedema in severely obese patients
}

\section{Resultado do tratamento cirúrgico do linfedema maciço localizado em pacientes obesos graves}

Wilson Cintra Júnior, TCBC-SP1; Miguel Luiz Antonio Modolin, ECBC-SP1; Rodrigo ltocazo Rocha'; Thadeu Rangel Fernandes'; Ariel Barreto Nogueira ${ }^{2}$; Rolf Gemperli,TCBC-SP3

A B S T R A C T

\begin{abstract}
Objective: to evaluate the importance of treatment of deformities caused by massive localized lymphedema (MLL) in the severely obese. Methods: in a period of seven years, nine patients with morbid obesity and a mean age of 33 years underwent surgical resection of massive localized lymphedema with primary synthesis. This is a retrospective study on the surgical technique, complication rates and improved quality of life. Results: all patients reported significant improvement after surgery, with greater range of motion, ambulation with ease and more effective hygiene. Histological analysis demonstrated the existence of a chronic inflammatory process marked by lymphomonocitary infiltrate and severe tissue edema. We observed foci of necrosis, formation of microabscesses, points of suppuration and local fibrosis organization, and pachydermia. The lymphatic vessels and some blood capillaries were increased, depicting a framework of linfangiectasias. Conclusion: surgical treatment of MLL proved to be important for improving patients' quality of life, functionally rehabilitating them and optimizing multidisciplinary follow-up of morbid obesity, with satisfactory surgical results and acceptable complication rates, demonstrating the importance of treatment and awareness about the disease.
\end{abstract}

Key words: Lymphedema. Lymphedema/etiology. Lymphedema/pathology. Lymphedema/surgery. Obesity, morbid/ complications.

\section{INTRODUCTION}

O bese patients frequently have edema or even lymphedema of the lower extremities', yet the localized massive lymphedema (MLL) is poorly observed and results from impaired lymphatic drainage, forming large tumor masses, especially in the lower limbs and hypogastrium ${ }^{2-4}$. MLL was preliminarily described by Goshtarby et al. ${ }^{4}$ and Farshid et al. ${ }^{5}$, who established the distinction with differentiated liposarcoma.

Beyond the deforming character, MLL determines mobility limitation, the main reason for seeking treatment. Beside this, the huge tumor mass hinders local hygiene, thus allowing accumulation of debris and recurrent infectious episodes of cellulitis, worsening symptoms $2,6,7$.

This paper assesses the importance of the surgical treatment of massive localized lymphedema in severely obese patients.

\section{METHODS}

Between 2005 and 2012, nine patients were treated, six of them male. The mean age was 33 years, ranging between 19 and 57 . The body mass index ranged from $44.1 \mathrm{~kg} / \mathrm{m}^{2}$ and $86.0 \mathrm{~kg} / \mathrm{m}^{2}$, with an average of 62.4 . Six patients had a deformity in the anteromedial thigh (Figure 1) and three in the hypogastrium (Figure 2). All reported that the onset and development of the tumor occurred after repeated episodes of skin infection, which were treated with local care and eventual antibiotic therapy, which did not prevent increase tumor.

Treatment consisted of resection of the masses, including margins of 1 to $2 \mathrm{~cm}$ of apparently non-compromised skin. The remaining wounds were closed with flaps of healthy neighbor skin, the weight of the MLL mass having promoted due distention. The syntheses were carried out with separate 4-0 and 5-0 polyamide stitches. Drainage was performed under vacuum with a chest tube in a closed system. Bleeding was compatible with the size of the tumor. Despite the rigorous

1. Department of Plastic Surgery, Clinics Hospital, Faculty of Medicine, University of São Paulo; 2. Division of Pathology, Clinics Hospital, Faculty of Medicine, University of São Paulo; 3. Department of Plastic Surgery, Faculty of Medicine, University of São Paulo. 


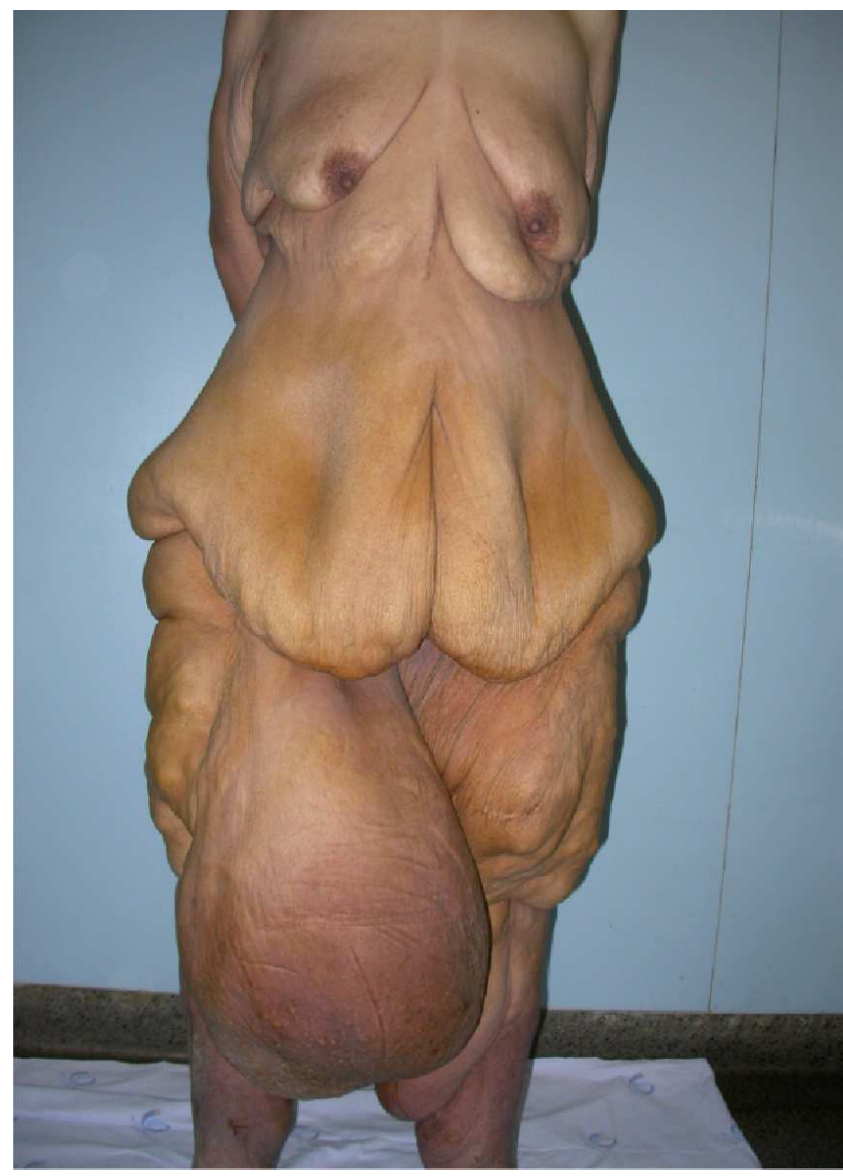

Figure 1 - Example of MLL on the right thigh.

hemostasis, one patient required volume and blood replacement for correction of instituted anemia.

All patients received antibiotic prophylaxis initiated 30 minutes prior to the procedure, maintained for up to 48 hours, and prophylaxis for deep venous thrombosis with enoxaparin beginning 12 hours after the operation and continued for seven days.

The dressings were prepared daily with surgical gauze, tapes and bandages, after cleaning of the surgical wounds.

All specimens removed were sent to histopathology.

\section{RESULTS}

All patients reported marked improvement thanks to the comfort of the withdrawal of the tumor mass, greater range of motion and greater ease of ambulation, and the possibility of more effective hygiene. The weights and volumes of the removed parts are shown in Table 1. The average weight was $7.8 \mathrm{~kg}$ and the average volume of $17.655 \mathrm{~cm}^{3}$.

In all patients, we observed a marbling appearance of the subcutaneous tissue and output of

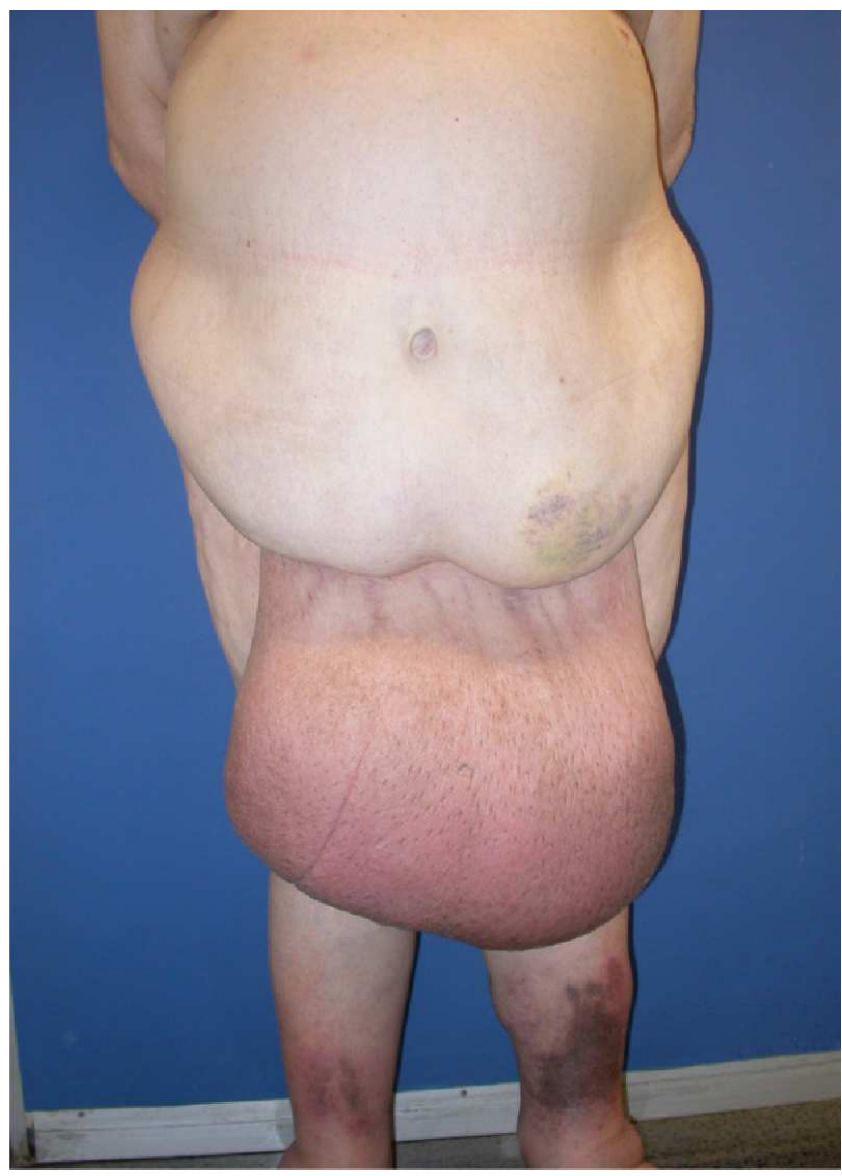

Figure 2 - Example of MLL in the suprapubic region.

large amount of hyaline liquid during tumor resection (Figure 3).

The skin of the tumor region had, in all cases, pachydermia features and presence of warty, scattered lesions, varying from 1 to $5 \mathrm{~cm}$ in size.

In the postoperative period there was drainage of large amounts of fluid, initially sero-hematic, and after three or four days, hyaline, with daily volume of about $600 \mathrm{ml}$, $1270 \mathrm{ml}$ being the largest and $20 \mathrm{ml}$ the smallest. Such drainage persisted for two to three weeks and gradually regressed spontaneously.

The length of stay ranged from one to 21 days. Two patients had local complications: one had wound dehiscence, requiring a new suture; another had wound infection, with phlegmonous cellulitis, requiring hospitalization with parenteral antibiotics. Both had good response to treatment, without further complications. These two patients had higher values of BMI, 71 and 86, respectively. There were no other complications demanding greater care, except for small dehiscences along the wound, which occurred in all cases, and healed by secondary intention.

One patient had recurrence of the disease, requiring two new approaches for resection of the tumor mass. 
Tabela 1 - Mensuração das peças cirúrgicas relacionadas com os valores do IMC.

\begin{tabular}{lcccc}
\hline Paciente & IMC $\left(\mathrm{kg} / \mathrm{m}^{2}\right)$ & Peso da peça $(\mathrm{g})$ & Medidas da peça $(\mathrm{cm})$ & Volume da peça $\left(\mathrm{cm}^{3}\right)$ \\
\hline $1-\mathrm{NS}$ & 44,1 & 715 & $25 \times 17 \times 3$ & 1275 \\
$2-$ AP & 53,8 & 5490 & $28 \times 24 \times 3$ & 2076 \\
$3-$ CT & 73,1 & 18000 & $50 \times 43 \times 12$ & 25800 \\
$4-$ LC & 5250 & $38 \times 23 \times 11$ & 9614 \\
$5-$ RB & 60,4 & 22000 & $65 \times 60 \times 17$ & 66300 \\
$6-$ KC & 13870 & $44 \times 42 \times 11$ & 20328 \\
$7-$ DT & 86,0 & 9000 & $40 \times 25 \times 14$ & 14000 \\
$8-$ CM & 50,0 & 6210 & $34 \times 30 \times 10$ & 10200 \\
$9-$ EP & 69,4 & 5900 & $46 \times 32 \times 7$ & 10304 \\
MÉDIA & 71,0 & 7800 & - & 17655 \\
\hline
\end{tabular}

The histological results showed chronic inflammatory process, marked by lymphomonocitary infiltrate, accompanied by severe tissue edema. In some areas foci of necrosis were noted, with formation of microabscesses and points of suppuration. In other areas the organization of local fibrosis could be seen. Lymphatic vessels, as well as some blood capillaries, were increased, defining histopathological features of lymphangiectasia. The epidermis was acanthotic, featuring pachydermia (Figure 4).

\section{DISCUSSION}

The modern concepts of MLL are assigned to Farshid and Weiss ${ }^{5}$, which, in 1998, managed to gather 14 cases with lower limb injuries. These pathologists highlighted

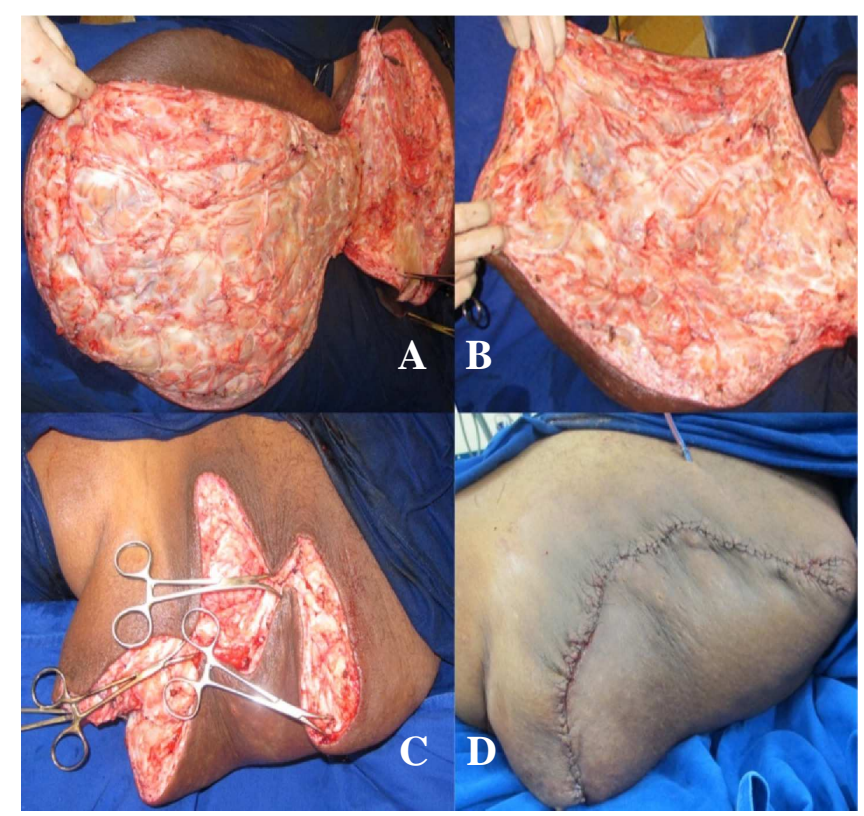

Figure 3 - $\quad A, B$ : marble feature of the MLL subcutaneous tissue. $C, D$ : closing of the wound without difficulty, at the expense of a neighborhood flap. the salient features of this pathology, rendering less likely the confusion with well-differentiated liposarcoma. Still, other names such as lynphodystrophic tissue, pseudosarcomas, fibrolipoangiolipomatous hamartoma and elephantiasis nostra, can be found in the literature ${ }^{4,7-16}$.

The lower limbs are typical locations of MLL, but in some cases they also appear in the inguinal and suprapubic areas. Penile and scrotal masses were also identified ${ }^{8,9}$, but were not included in this series. MLL is acquired in adulthood, growing insidiously and silently over the years, interfering with ambulation and hygiene, which, once committed, is a constant point of dermatitis and ulceration.

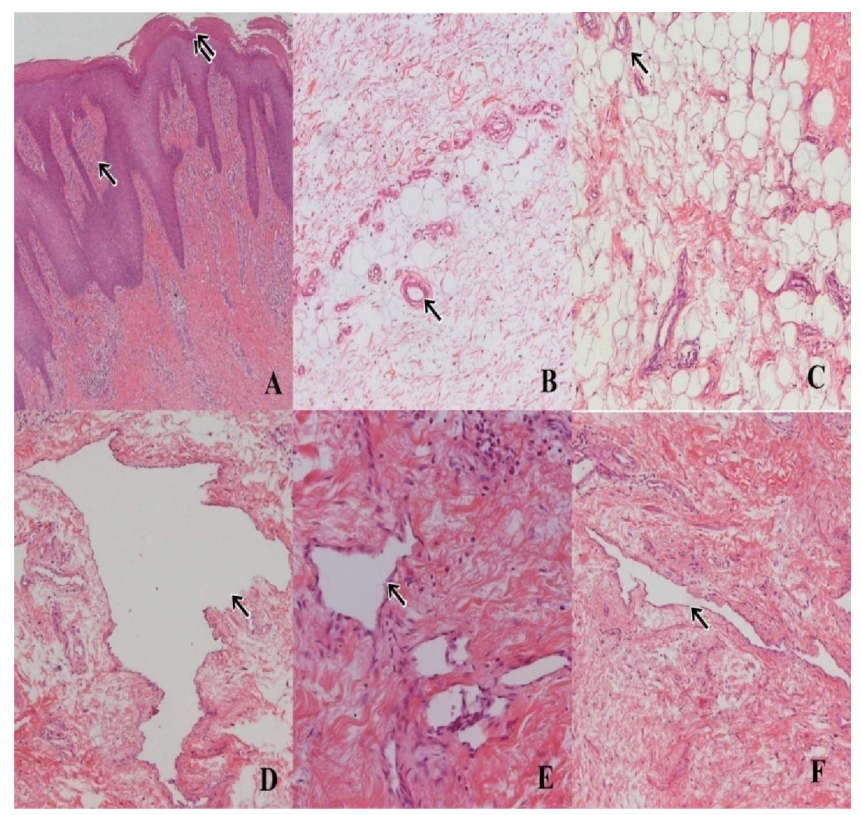

Figure 4 - A: Skin with irregular acanthosis (two arrows) and fibrosis of skin healing pattern (arrow) - (100x magnification), B, C: Adipose tissue with vascular proliferation (arrows) and interstitial edema (200x magnification), D, F (200x magnification) and E (400x magnification): irregular dilated lymphatic vessels (arrow) and edema characteristic of lymphedema. Staining: hematoxylin-eosin. 
The histopathological diagnosis is evidenced by widespread interstitial edema, associated with reactive fibroblast proliferation, acanthosis and dermal sclerosis, vascular and lymphatic ectasia, with inflammation. Macroscopically, the hardened tumor mass and the skin with the "orange peel" appearance feature the frequent pachydermia that accompany MLL, 4,-10.

Any lymphatic obstruction may precipitate regional lymphedema. In this sense, the differential diagnosis should be made with either congenital malformations and acquired conditions, including lipomas, sarcomas and other tumors, sequelae of surgery, radiation therapy, trauma and filariasis. Lipodystrophy and massive abdominal panicles may also be involved ${ }^{8-11}$.

The precise mechanism of the formation of MLL remains intact. Descriptions in the literature suggest that the formation of lymphedema is due to obstruction of the initial lymphatic system and its consequent congestion. The extravasation of protein-rich fluid to the interstitial space stimulates localized inflammatory response, hampering lymph drainage, which causes chronic lymphedema ${ }^{12}$. The normal lymph transport depends on intrinsic contractility of the lymphatic system, with directional flow provided by the presence of valves. Extrinsic factors, such as exercise, daily activities and external compression, also play an important role to prevent lymphatic congestion. In patients with a high BMI, given the higher level of interstitial fluid resulting from a greater volume of adipose tissue, there is increased pressure, thereby compromising lymph draining. Consequently, the body condition of these patients causes a significant obstacle to mechanical lymphatic drainage ${ }^{10,11}$, which worsens with inactivity.

All cases of MLL in obese are described in hanging areas of the abdomen and lower limbs. Therefore, it can be inferred that the lesion is a result of lymphatic stasis exacerbated by increasing of fat in hanging areas, as well as the motion reduction of the obese patient ${ }^{13}$.

Undoubtedly, in the morbidly obese local hygiene is poor due to the difficulty of access between fat-skin folds. When associated with flaking skin and natural secretions, this constitutes a fertile ground for installation of infections, generically called intertrigo. The recurrence of these infections causes lymphangitis, which increases in the lower segments of the trunk, ie, hypogastrium and lower limbs due to the consequent stasis. Lymphangitis stasis determines leakage of lymphatic fluid, which stimulates cell proliferation, both on the epidermis, which is thickened and grows warts, and in deeper layers, where the inflammatory process develops. This lymphedema framework, associated with the local inflammatory reaction, distends the tissues and increases tissue ischemia, which causes severe fibrosis with interspersed fatty tissue, generating septa and blocks. The evolution of is progressive and results in the appearance of localized tumor masses $2,5,10$.

Within this context, in all our patients the predisposing factor was obesity and the described etiopathogenic mechanism was triggering by infection, due to favorable local conditions. However, one cannot rule out that the same lymphatic drainage disorder is a result of obesity alone, running parallel to the two theories previously mentioned ${ }^{7,10}$.

The possibility of recurrence cannot be overlooked ${ }^{4,7,8,10}$. The presence of the pedicle at the base of the tumor and no involvement of the deep layers below the muscle-aponeurotic fascia generally facilitate surgical resection. In our series there was a patient who demanded two reoperations, since committed tissue remained in the previous procedures due to difficulty in finding a plane of dissection, which favored recurrence. Nevertheless, the results were cosmetic and functionally appropriate, as they favored ambulation and allowed effective hygiene.

This experience reinforces the profile of MLL as rare, but it can become a serious chronic problem, rendering the patient incompetent. Unlike ordinary mild edema or lymphedema, treatment with bariatric surgery and weight loss does not excuse the complete and curative surgical removal. Obesity, and its comorbidities, does not limit the obligation of the resection of the tumor mass, despite the inherent risks. Surgical treatment requires a prolonged postoperative period, but all patients were discharged in good condition. Functional rehabilitation was achieved.

Surgical treatment of MLL was important to improve the quality of life, functionally rehabilitating and optimizing the multidisciplinary follow-up of morbid obesity, with satisfactory surgical results and acceptable complication rates, demonstrating the importance of its application in the treatment of massive localized lymphedema.

\section{R E S U M O}

\footnotetext{
Objetivo: avaliar a importância do tratamento das deformidades ocasionadas pelo linfedema maciço localizado (LML) em obesos. Métodos: em um período de sete anos, nove pacientes portadores de obesidade mórbida e com média etária de 33 anos, foram submetidos à ressecção cirúrgica de linfedema maciço localizado e síntese primária. Trata-se de estudo retrospectivo sobre a técnica cirúrgica empregada, incidência de complicações e melhora da qualidade de vida dos pacientes. Resultados: todos os pacientes relataram expressiva melhora após o tratamento cirúrgico, apresentando maior amplitude de movimentos, com desenvoltura da deambulação e possibilidades de higiene mais efetivas. As análises histológicas demonstraram a existência de processo inflamatório crônico marcado por infiltrado linfomonocitário, acompanhado de grande edema tecidual. Foram constatados focos de necrose, formação de microabcessos, pontos de supuração e organização de fibrose local e paquidermismo. Os vasos linfáticos e alguns capilares sanguíneos apresentavam-se aumentados, definindo um quadro de linfangiectasias. Conclusão: o tratamento cirúrgico
} 
do LML mostrou-se importante para a melhora na qualidade de vida desses pacientes, reabilitando-os funcionalmente e otimizando o seguimento multidisciplinar da obesidade mórbida, com resultados cirúrgicos satisfatórios e taxas aceitáveis de complicações, demonstrando a importância do tratamento e da consciência sobre a doença.

Descritores: Linfedema. Linfedema/etiologia. Linfedema/patologia. Linfedema/cirurgia. Obesidade Mórbida/complicações.

\section{REFERENCES}

1. Yosipovitch G, DeVore A, Dawn A. Obesity and the skin: skin physiology and skin manifestations of obesity. J Am Acad Dermatol. 2007;56(6):901-16; quiz 917-20.

2. Warren AG, Brorson H, Borud LJ, Slavin SA. Lymphedema a comprehensive review Ann Plast Surg. 2007;59(4):464-72.

3. Scheinfeld NS. Obesity and dermatology. Clin Dermatol. 2004;22(4):303-9.

4. Goshtarby P, Dawson J, Agarwal N. Pseudosarcoma: massive localized lymphedema of the morbidly obese. Obes Surg. 2006; 16(1):88-93.

5. Farshid G, Weiss SW. Massive localized lymphedema in the morbidly obese: a histologically distinct reactive lesion simulating liposarcoma. Am J Surg Pathol. 1998;22(10):1277-83.

6. Modolin ML, Cintra W Jr, Paggiaro AO, Faintuch J, Gemperli R, Ferreira MC. Massive localized limphedema (MLL) in bariatric candidates. Obes Surg. 2006;16(9):1126-30.

7. Vána J, Adamicová K, Haluska P, Celec J. Massive localized lymphedema in an extremely obese patient. Chirurg. 2002;73(4):383-6.

8. Decker P, Görtz M, Sigmund G, Kriegsmann J, Decker D. Massive localized lymphedema - a rare entity. Zentralbl Chir. 2003;128(11):985-7.

9. Oswald TM, Lineaweaver W. Limited segmental resection of symptomatic lower-extremity lymphodystrophic tissue in high-risk patients. South Med J. 2003;96(7):689-91.

10. Modolin M, Mitre Al, da Silva JC, Cintra W, Quagliano AP, Arap S, et al. Surgical treatment of lynphedema of the penis and scrotum. Clinics. 2006;61(4):289-94.
11. Asch S, James WD, Castelo-Soccio L. Massive localized lymphedema: an emerging dermatologic complication of obesity. J Am Acad Dermatol. 2008;59(5 Suppl):S109-10.

12. Barr J. Massive localized lymphedema of suprapubic origin. Plast Reconstr Surg. 2000;106(7):1663-4.

13. Hanna D, Cloutier R, Lapointe R, Desgagné Al. Abdominal elephantiasis: a case report. J Cutan Med Surg. 2004;8(4):229-32.

14. Wu D, Gibbs J, Corral D, Intengan M, Brooks JJ. Massive localized lymphedema: additional locations and association with hypothyroidism. Hum Pathol. 2000;31(9):1162-8.

15. Burri H, Loutan L, Kumaraswami V, Vijayasekaran V. Skin changes in chronic lymphatic filariasis. Trans R Soc Trop Med Hyg. 1996:90(6):671-4.

16. Bannerjee D, Williams EV, llott J, Monypenny IJ, Webster DJ. Obesity predisposes to increased drainage following axillary node clearance: a prospective audit. Ann R Coll Surg Engl. 2001;83(4):268-71.

Received on 15/10/2012

Accepted for publication 15/12/2012

Conflict of interest: none.

Source of funding: none.

\section{How to cite this article:}

Cintra Júnior W, Modolin MLA, Rocha RI, Fernandes TR, Nogueira AB, Gemperli R, Ferreira MC. Results of surgical treatment of massive localized lymphedema in severely obese patients. Rev Col Bras Cir. [periódico na Internet] 2014;41(1). Disponível em URL: http:// www.scielo.br/rcbc

Address for correspondence:

Cintra Wilson Junior

E-mail:wcintra@terra.com.br 